Article

\title{
Energy Analysis of a Rotary Drum Bioreactor for Composting Tomato Plant Residues
}

\author{
Fahad N. Alkoaik 1,* Ahmed M. Abdel-Ghany ${ }^{1}$ (i), Mohamed A. Rashwan 1,2, \\ Ronnel B. Fulleros ${ }^{1}$ and Mansour N. Ibrahim ${ }^{1}$ \\ 1 Department of Agricultural Engineering, College of Food and Agriculture Sciences, King Saud University, \\ Riyadh 11451, Saudi Arabia; aghany@ksu.edu.sa (A.M.A.-G.); mrashran.c@ksu.edu.sa (M.A.R.); \\ rfulleros@ksu.edu.sa (R.B.F.); malsamee@ksu.edu.sa (M.N.I.) \\ 2 Department of Agriculture and Biosystems Engineering, Faculty of Agriculture, Alexandria University, \\ Alexandria 21526, Egypt \\ * Correspondence: falkoaik@ksu.edu.sa
}

Received: 7 December 2017; Accepted: 14 February 2018; Published: 19 February 2018

\begin{abstract}
Energy produced from plant residue composting has stimulated great interest in heat recovery and utilization. Composting is an exothermic process often controlled through temperature measurements. However, energy analysis of the overall composting system, especially the rotary bioreactors, is generally not well known and very limited. This study presents detailed energy analysis in a laboratory-scale, batch-operated, rotary bioreactor used for composting tomato plant residues. The bioreactor was considered as a thermodynamic system operating under unsteady state conditions. The composting process was described, the input generated and lost energy terms as well as the relative importance of each term were quantitatively evaluated, and the composting phases were clearly identified. Results showed that the compost temperature peaked at $72 \mathrm{~h}$ of operation reaching $66.7^{\circ} \mathrm{C}$ with a heat generation rate of $9.3 \mathrm{~W} \cdot \mathrm{kg}^{-1}$ of organic matter. During the composting process, the accumulated heat generation was $1.9 \mathrm{MJ} \cdot \mathrm{kg}^{-1}$ of organic matter; only $4 \%$ of this heat was gained by the composting material, and $96 \%$ was lost outside the bioreactor. Contributions of thermal radiation, aeration, cylindrical, and side-walls surfaces of the reactor on the total heat loss were $1 \%, 2 \%, 69 \%$, and $28 \%$, respectively. The information obtained is applicable in the design, management, and control of composting operations and in improvement of bioreactor effectiveness and productivity.
\end{abstract}

Keywords: composting; tomato plant residues; heat generation; loss; rotary bioreactor

\section{Introduction}

In Saudi Arabia, tomato crop represents $15.5 \%$ of the total cultivated area, producing about 0.5 million tons per year, and greenhouse production represents $58 \%$ of the greenhouse total vegetable production, with a production area of 1550 hectares, yielding about 0.2 million tons per year [1]. Typical vegetable greenhouse operations produce 40-60 tons of organic residues per hectare per year [2]. Accordingly, the greenhouse industry in Saudi Arabia currently produces over than 0.3 million tons of organic wastes per year [2]. There is a considerable amount of tomato plant residue, as a result of trimming and harvesting the crop that must be disposed-off properly $[2,3]$. Composting of plant residues is considered to be the most desirable organic waste management method [3]. Traditional composting systems are open, include agitated (windrow) and static solids beds; they require a large space and longtime of composting process (i.e., 1-2 years, on average) [4]. Enclosed or in-vessel systems use fixed or rotary bioreactors for composting have been developed. These systems can process large amounts of waste without taking up much space, and they offer good control of the environmental conditions such as temperature, moisture content, and airflow rate [5]. Rotary drum 
bioreactors are considered to be an efficient and promising technology, as this type of composters are enclosed, provide agitation, aeriation, and compost mixing, and produce a consistent and uniform end product without any odor or leachate related problems [6]. In which the composting time is drastically reduced to 2-3 weeks [7]. The majority of agricultural residues are generated at the end of the season at once. In addition, in a continuous system, the possibility of mixing fresh material with composted one can occur. Therefore, in agricultural practice, a batch operating systems is preferred to insure product hygiene [2]. Previous studies used rotary drum bioreactors, and the drums were turned manually from time to time during composting process. Therefore, the effect of turning frequency $(6,12,18$, and $24 \mathrm{~h}$ interval times between two turning operations) on the stability of compost and composting performance was examined [8]. However, the composting performance of a continuously rotating bioreactor (at low speeds) has never been evaluated in previous studies.

Organic waste composting produces a considerable amount of heat due to heat liberation from microbial metabolic activity, and an elevated temperature of the system $\left(70-90^{\circ} \mathrm{C}\right)$ may be achieved during composting of municipal solid waste $[9,10]$. Therefore, understanding and exploring energy generation and transfer phenomena during composting is essential for controlling, managing and optimizing the composting processes. On the other hand, Rodriguez, L. et al., (2012) [11] reported that by optimizing the operating conditions during the thermophilic stage, the process could be sped up and useful compost could be provided in less time; therefore, it is important to optimize the operating conditions to reduce the composting time as much as possible [11]. Moreover, temperatures from 52 to $60^{\circ} \mathrm{C}$ are considered to maintain the greatest thermophilic activity in composting systems; this range of temperatures reduces weed seed viability and suppresses pathogens activity during composting $[7,8]$. Accordingly, quantifying the generated and lost energy terms during composting is the key factor for managing and improving bioreactor performance. In the previous literature, a limited number of studies have investigated the potential energy content of compost. All focused on the in-vessel fixed bioreactors, and some of them have calculated the generated heat during composting. For example, the heat produced during composting of wheat straw was calculated to be $17.06 \mathrm{MJ} \cdot \mathrm{kg}^{-1}$ of organic substances [12], during composting of poultry droppings was $12.8 \mathrm{MJ} \cdot \mathrm{kg}^{-1}$ of organic substances [13], during composting of tomato plant residues-wood shavings-municipal solid mixture was $570 \mathrm{~kJ} \cdot \mathrm{kg}^{-1}$ of degraded dry mass [14], during composting of poultry manure-wood shavings mixture was 16-19 MJ $\mathrm{kg}^{-1}$ of volatile solid of mixture [15], during composting of municipal waste was $1.136 \mathrm{MJ} \cdot \mathrm{kg}^{-1}$ of degraded matter [16], and during composting of green waste, industrial sludge, liquid waste, and sewage was in the range from 7 to $10 \mathrm{MJ} \cdot \mathrm{kg}^{-1}$ of organic matter degraded [17]. Even though previous studies have focused on estimating the heat generation in fixed bioreactors, the heat losses during the composting process have not received much attention. Bach et al. [18] reported that, the heat loss from the reactor walls was the largest term in the laboratory-scale bioreactor, while heat removal by water evaporation was the largest in the commercial bioreactor. Ghaly et al. [14] reported that the heat losses from the side walls of bioreactors were accounted to be $30-90 \%$ of the total heat generated based on the insulation effectiveness of the bioreactor. The heat generation rate during the composting process is a function of chemical, physical, and biological properties of the composted material; therefore, the previous studies reported wide variations in the amount of heat $\left(0.5-20 \mathrm{MJ} \cdot \mathrm{kg}^{-1}\right)$ released from organic material decomposition. Also, wide variations in the amount of heat losses (30-90\% of heat generation) were reported [14-23]. Moreover, previous studies dealt with fixed or manually rotated (from time to time) drum composters to account for the amount of heat generation and/or losses during composting process. However, information on the heat generation and losses during the composting process of a continuously rotating (at low speed) bioreactor are still missing. Such information is essential to maintain the composting process at optimum temperature and to evaporate moisture from solid reactants to produce compost at low moisture content. In addition, quantifying the energy terms during the reaction process of this type of composter is necessary to reduce the heat losses and to increase the production rate of compost within a short time. 
Accordingly, the objective of this study is to provide thermal analysis of composting tomato plant residues in a laboratory-scale rotary drum bioreactor (i.e., continuously rotating at low speed of $3 \mathrm{rpm}$ ) and to evaluate the relative importance of each energy term relating to the total generated heat. The analysis will be performed in unsteady state conditions. Such information will be helpful in the proper design and optimum operation of rotary drum bioreactors.

\section{Materials and Methods}

\subsection{Plant Residues}

Greenhouse tomato fresh plant residues (leaves, stems, and some green and damaged fruits) were collected from various fields in Riyadh, Saudi Arabia. The average moisture content (MC) of the collected residues was about $90 \%$. Then, they were spread out on the ground to dry for three days (MC 60\%). The residues were chopped using a gas motor-powered shredder (model FYS-76 Shredder, Mainland, Zhejiang, China) to promote better aeration and moisture control. Grinding was performed to decrease the particle size to about $1 \mathrm{~cm}$ in order to boost the microbial degradation process. The grinded residues were left to dry out for an additional two consecutive days on the floor (MC 15\%), then transported to the Biological Lab at the Research Station, Agricultural Engineering Department, King Saud University, Riyadh, and placed inside a refrigerator at $4{ }^{\circ} \mathrm{C}$ until used.

\subsection{Experimental Apparatus}

Three identical pilot scale rotary drum bioreactors (each with a volume of $200 \mathrm{~L}$ ) were constructed in the laboratory at the Research Station, Agricultural Engineering Department, King Saud University, (Riyadh, Saudi Arabia, $46^{\circ} 47^{\prime} \mathrm{E}$, longitude and $24^{\circ} 39^{\prime} \mathrm{N}$, latitude). Each bioreactor was designed to provide a space for $50 \mathrm{~kg}$ (wet bases) of compost mixture plus $25 \%$ of the volume as a head space. Each bioreactor is a steel barrel with an inner diameter of $585.0 \mathrm{~mm}$, length of $914.4 \mathrm{~mm}$, and wall thickness of $0.9 \mathrm{~mm}$. In each bioreactor, an opening door of $50 \times 40.5 \mathrm{~cm}$ was made for loading, unloading, sampling, and cleaning purposes. A rubber gasket lining was fixed on the inner side of each opening door to keep it tight and to prevent any leakage. The outer surfaces of each reactor were insulated with a layer of $25 \mathrm{~mm}$-thick glass wool blanket. Each reactor rotates horizontally around a fixed axis (a steel tube, $50 \mathrm{~mm}$ outer diameter) at $3 \mathrm{rpm}$ by using a $0.25 \mathrm{HP}$ electric motor (model no. 220-380-3, Zhejiang, China). The perimeter of the tube in each reactor includes on-line holes distributed longitudinally in the upper surface of the tube for aeration purposes. Layout dimensions for the constructed rotary drum reactor, installed on a steel-angle frame with the rotating system, are illustrated, not to scale, in Figure 1.
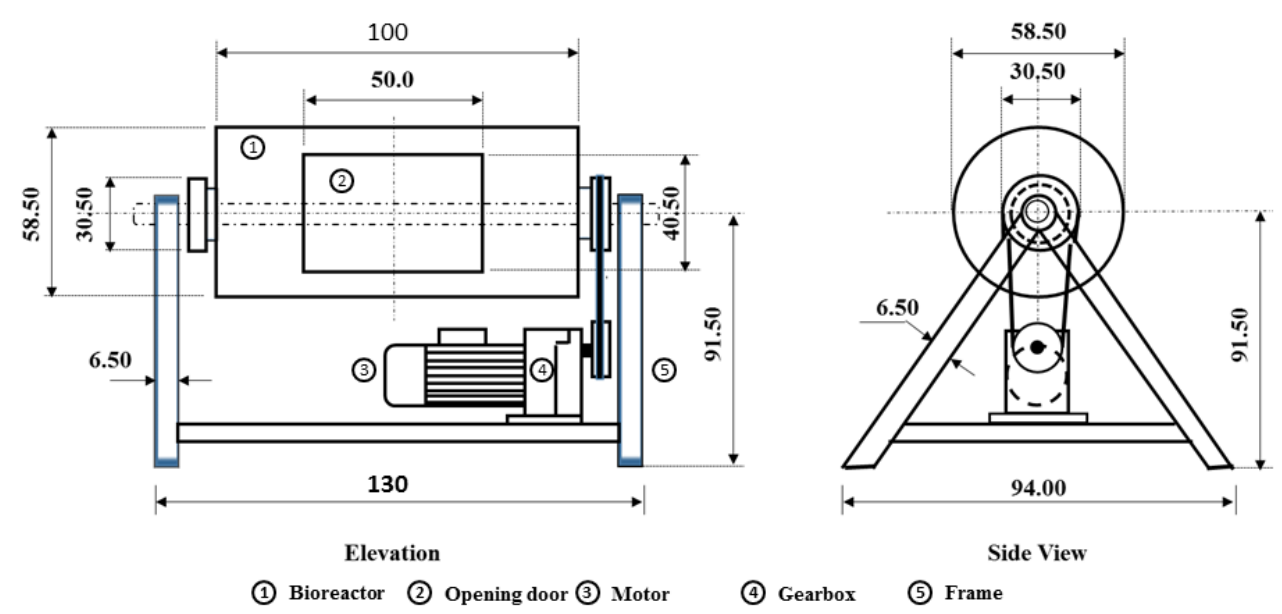

Figure 1. Schematic diagram showing two views of the constructed rotary drum bioreactor system; dimensions in $\mathrm{cm}$, not to scale. 


\subsection{Experimental Procedure and Measurements}

For aeration in each reactor, compressed air was supplied continuously at a flow rate of $0.005 \mathrm{~m}^{3} \cdot \mathrm{min}^{-1}$ from a reservoir (10 bar, $0.2 \mathrm{~m}^{3}$ volume) connected with an air compressor (Airmac, CRM203, $2.2 \mathrm{~kW}$, Parkinson, Australia). The compressed air was supplied to the horizontal tube that the reactor rotates around. The compressed air passes through a flow meter that can regulate the flow rate of air in the range of $0.001-0.025 \mathrm{~m}^{3} \cdot \mathrm{min}^{-1}$, and then to the compost via on-line holes that were made in the upper side of the horizontal tube (Figure $2 \mathrm{a}$ ). The temperature of the compost $\left(T_{\mathrm{c}}\right)$ was measured using four thermocouple sensors fixed longitudinally at four locations below the horizontal tube (see Figure 2b). In the tube, the holes for aeration were on the upper side, while the thermocouple sensors were fixed on the lower side to be far enough from the inlet air to minimize the negative influence of air on the measured temperature. Temperatures of the outer surface of insulation $\left(T_{\mathrm{S}}\right)$ and the outer and inner surfaces of the barrel $\left(T_{\mathrm{o}}\right.$ and $T_{\mathrm{i}}$ ) were measured using thermocouple sensors attached properly to the surfaces. The thermocouples used were copper-constantan, (type-T, Cole Parmer, Chicago, IL, USA). The wires of the four sensors used to measure $T_{\mathrm{C}}$ were passed inside the tube to the outside and connected to a portable data logger (Testo 177-T4 V01-02), fixed at the end of the tube, to record the measured temperatures. The wires of the thermocouple sensors used to measure $T_{\mathrm{i}}, T_{\mathrm{O}}$, and $T_{\mathrm{S}}$ were connected to another portable data logger (Testo 177-T4 V01-02) fixed at the outer surface of the reactor. The ambient temperature $\left(T_{\mathrm{am}}\right)$ and relative humidity $\left(\mathrm{RH}_{\mathrm{am}}\right)$ were measured using Thermo-hygrometer DMA033 (LSI-Lastem, Milano, Italy). The measured parameters were recorded every 10 seconds, averaged every $10 \mathrm{~min}$, and saved in the data loggers.

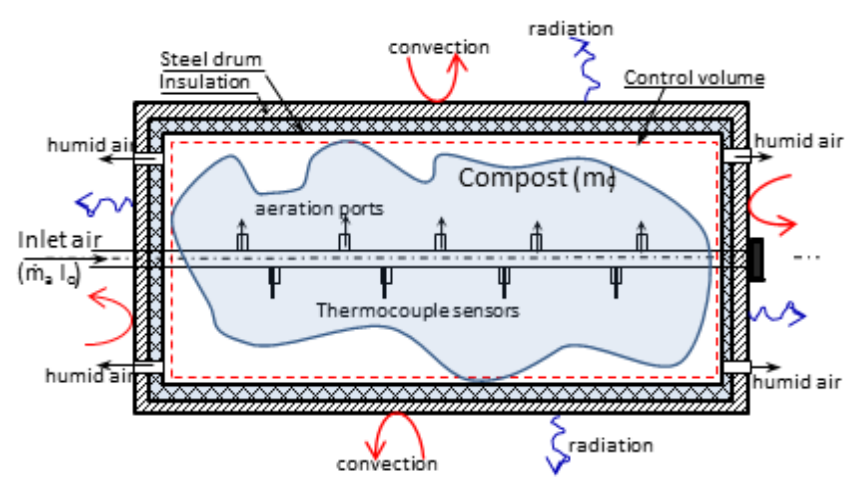

Section elevation

(a)

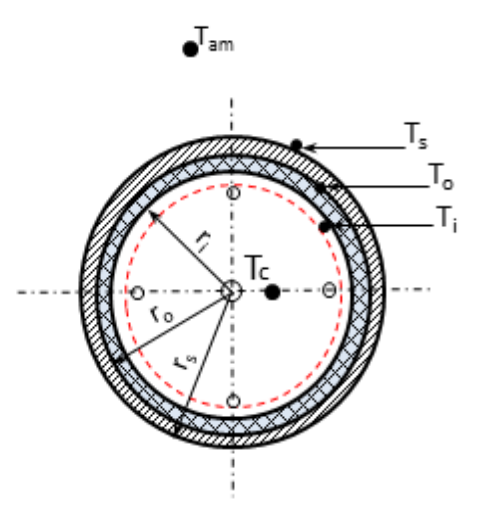

Section side view

(b)

Figure 2. Cross sectional views of the bioreactor showing: (a) the air inlet and outlet ports, the horizontal tube including the aeration ports and the thermocouples supports, and the energy terms cross the suggested control volume, and (b) thermocouple sensor locations in the bio-reactor.

Tomato residues and chicken manure (20\% dry weight) were mixed properly. At the beginning of the experiment, moisture content of the mixture was adjusted to be about $60-65 \%$ and $\mathrm{C} / \mathrm{N}$ ratio at about 30:1. After that, the mixture was transferred to the three bioreactors (each was filled up to $75 \%$ of the total volume) initiating the active phase of the composting process. The active phase continued until the bioreactor average temperature dropped below $35^{\circ} \mathrm{C}$. Compost materials were then transferred outside the bioreactors and left for curing for an additional 30-60 days. During the curing phase, only moisture content was monitored to ensure the completion of the degradation process.

\subsection{Energy Analysis}

The bioreactor was considered as an open thermodynamic system in the un-steady state condition; the compost-humid air mixture in the bioreactor enclosed by a control volume suggested being the size 
of the space inside the bioreactor (Figure 2a). To describe the energy exchange between the different components of the bioreactor and to quantify the different energy terms, energy balance was applied to the control volume under the unsteady-state condition, assuming the following: (i) The moist air and the compost inside the reactor are well mixed and characterized by an average temperature, $T_{\mathrm{c}}$. (ii) The thermophysical properties of the compost and moist air are equivalent properties independent of temperature, and the pressure inside the bioreactor is the atmospheric pressure. The air enters the bioreactor at the atmospheric conditions $\left(T_{\mathrm{am}}, R H_{\mathrm{am}}\right)$ and exits nearly saturated $\left(T_{\mathrm{c}}, R H \sim 0.95\right)$. (iii) Parameters in the upcoming analysis are time dependent and to simplify the expressions, time $t$ is omitted from all the symbols hereafter.

The energy balance equation that describes the different mode of energy crossing the boundary of the control volume (Figure $2 \mathrm{a}$ ) is given by

$$
E_{\mathrm{in}}+Q_{\mathrm{gn}}-E_{\mathrm{out}}=\frac{d}{d t}\left(I E_{\mathrm{c}}\right)
$$

where $E_{\mathrm{in}}$ is the rate of energy input to the control volume $(\mathrm{W}), Q_{\mathrm{gn}}$ is the generated energy rate due to the metabolic activity of compost $(\mathrm{W}), E_{\text {out }}$ is the rate of outlet energy leaving the control volume $(\mathrm{W})$, and $I E_{\mathrm{c}}$ is the internal energy of compost, gained or lost $(\mathrm{W})$. Descriptions of the energy terms in Equation (1) are as follows:

$$
E_{\text {in }}=\dot{m}_{\mathrm{a}} I_{\mathrm{am}} \text { and } E_{\text {out }}=\dot{m}_{\mathrm{a}} I_{\mathrm{e}}+Q_{\text {loss }}
$$

where $I_{\mathrm{am}}$ is the enthalpy of the ambient air $\left(\mathrm{kJ} \cdot \mathrm{kg}^{-1}\right), \dot{m}_{\mathrm{a}}$ is the flow rate of ambient air entering and leaving the bioreactor (i.e., used for aeration in $\mathrm{kg} \cdot \mathrm{s}^{-1}$ ), and $I_{\mathrm{e}}$ is the enthalpy of moist air $\left(\mathrm{kJ} \cdot \mathrm{kg}^{-1}\right)$, nearly saturated, exiting from the reactor at an equivalent temperature equal to the compost temperature $\left(T_{\mathrm{c}}\right)$. The enthalpy of air at inlet and exit of the bioreactor (i.e., estimated at $T_{\mathrm{am}}$ and $T_{\mathrm{c}}$ ) is reported by Abdel-Ghany et al. [24] as

$$
I=(1.007 T-0.026)+\omega(2501-1.84 T), \quad T \text { in }^{\circ} \mathrm{C}
$$

In Equation (3), the absolute humidity ( $\omega$ ) in $\mathrm{kg}$ of water vapor per $\mathrm{kg}$ of dry air is given by

$$
\omega=0.623 \frac{e}{(101.325-e)}, \text { and } e=R H \times e_{\mathrm{s}, T}
$$

where $e$ and $e_{\mathrm{s}, T}$ are the partial pressure of water vapor in the air and in the saturated air $(\mathrm{kPa})$, both at a certain temperature $T\left({ }^{\circ} \mathrm{C}\right)$ and at the atmospheric pressure. Value of $e_{\mathrm{s}, T}$ (in $\mathrm{kPa}$ ) is reported by Abdel-Ghany et al. [24] as

$$
e_{\mathrm{s}, T}=\operatorname{Exp}\left(\frac{16.78 T-116.9}{T+273.3}\right)
$$

The rate of change of the internal energy of compost, $d / d t\left[I E_{\mathrm{c}}\right]$, in Equation (1) over a small time interval, $\Delta t$, is given by

$$
\frac{d}{d t}\left(I E_{\mathrm{c}}\right)=m_{\mathrm{c}} C p_{\mathrm{c}} \frac{d T_{\mathrm{c}}}{d t}=m_{\mathrm{c}} C p_{\mathrm{c}} \frac{\Delta T_{\mathrm{c}}}{\Delta t}
$$

where $m_{\mathrm{c}}$ is the mass of compost $(\mathrm{kg})$, and $C p_{\mathrm{c}}$ is the specific heat of compost at constant pressure $\left(\mathrm{J} \cdot \mathrm{kg}^{-1} \cdot{ }^{\circ} \mathrm{C}^{-1}\right)$. The convective-radiative heat loss $\left(Q_{\text {loss }}\right.$ in $\left.\mathrm{W}\right)$ from the outer surface of the bioreactor to the surrounding air (Equation (2)) is given by

$$
Q_{\text {loss }}=Q_{\text {cylinder }}+Q_{\text {sid-wall }}=U_{\text {cy }} A_{\mathrm{cy}}\left(T_{\mathrm{c}}-T_{\mathrm{am}}\right)+U_{\mathrm{sw}} A_{\mathrm{sw}}\left(T_{\mathrm{c}}-T_{\mathrm{am}}\right)
$$

where $A_{\mathrm{cy}}$ and $A_{\mathrm{sw}}$ are the areas of the outer surfaces of the cylindrical part and of the side walls of the bioreactor $\left(\mathrm{m}^{2}\right)$ and $U_{\mathrm{cy}}$ and $U_{\mathrm{sw}}$ are the overall heat loss coefficient $\left(\mathrm{W} \cdot \mathrm{m}^{-2} \cdot{ }^{\circ} \mathrm{C}^{-1}\right)$ of the cylindrical part and of the side walls. $U_{\mathrm{cy}}$ and $U_{\mathrm{sw}}$ are equal to the inverse of the equivalent heat 
transfer resistances $\left(1 / R_{\text {eq-cy }}\right.$ and $\left.1 / R_{\text {eq-sw }}\right)$ between the compost having a temperature, $T_{\mathrm{c}}$ and the outside ambient air having a temperature, $T_{\mathrm{am}}$.

The heat transfer resistances between the compost and the ambient air (Figure 3) include (i) the thermal radiation resistance $\left(R_{\mathrm{r}}\right)$ between the outer surface of the bioreactor and the ambient air, (ii) the convective resistance $\left(R_{\mathrm{co}}\right)$ between the outer surface of the bioreactor and the ambient air, (iii) the conductive resistance $\left(R_{\mathrm{S}}\right)$ through the insulation thickness, (iv) the conductive resistance $\left(R_{\mathrm{o}}\right)$ through the drum steel-wall thickness, and $(\mathrm{v})$ the convective resistance $\left(R_{\mathrm{ci}}\right)$ between the compost-air mixture and the inner surface of the bioreactor. Diagrams of the resistances networks for the cylindrical part and side walls part are illustrated in Figure 3a,b. Diagrams for the elevation and side view cross sections to show the dimensions layout, radii, and length of each part in the bioreactor are illustrated in Figure 2a,b. The thermal resistances for the cylindrical part in Figure 3a are defined as follows:

$$
\begin{gathered}
R_{r}=\frac{1}{h_{r}\left(2 \pi r_{s} L\right)}, R_{c o}=\frac{1}{h_{c o}\left(2 \pi r_{s} L\right)}, R_{c i}=\frac{1}{h_{c i}\left(2 \pi r_{i} L\right)} \\
R_{o}=\frac{\ln \left(r_{o} / r_{i}\right)}{2 \pi K_{s} L}, R_{s}=\frac{\ln \left(r_{s} / r_{o}\right)}{2 \pi K_{b} L}
\end{gathered}
$$

In Equation (8a), $h_{\mathrm{r}}, h_{\mathrm{ci}}$, and $h_{\mathrm{co}}$ are the radiation heat transfer coefficient between the outer surface of the bioreactor and ambient air, the convective coefficient between the compost-moist air mixture and the inner surface of the bioreactor, and the convective coefficient between the outer surface of the bioreactor and ambient air $\left(\mathrm{W} \cdot \mathrm{m}^{-2} \cdot{ }^{\circ} \mathrm{C}^{-1}\right)$, respectively. The measured temperatures, $T_{\mathrm{i}}$ and $T_{\mathrm{c}}$, were almost similar during the experiment; therefore, the convective resistance at the inner surface of the bioreactor can be neglected $\left(R_{\mathrm{ci}}=0\right.$ and $R_{\mathrm{wi}}=0$, Figure $\left.3 \mathrm{a}, \mathrm{b}\right)$. In Equation $(8-\mathrm{b}), K_{\mathrm{s}}$ and $K_{\mathrm{b}}$ are the thermal conductivity of the drum material (steel) and of the insulation (glass wool) in $\mathrm{W} \cdot \mathrm{m}^{-1} \cdot{ }^{\circ} \mathrm{C}^{-1}$. The dimensions $r_{\mathrm{i}}, r_{\mathrm{o}}, r_{\mathrm{s}}$, and $L$ are illustrated in Figure 2a,b.
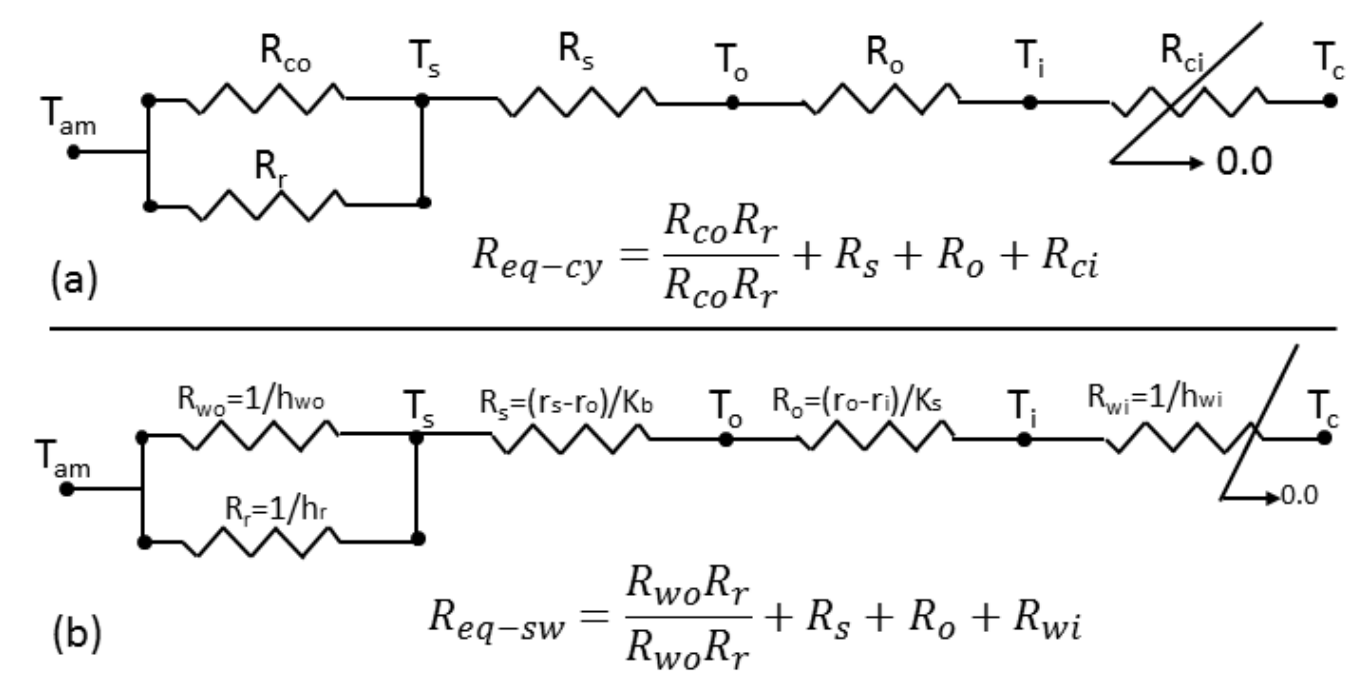

Figure 3. Electrical analogy for the thermal resistances against heat losses transmitted between the compost-moist air mixture and the outside ambient air (a) through the cylindrical part and (b) through vertical circular side walls.

The outer surface of the reactor exchanges thermal radiation with the inside surfaces of the laboratory building; by assuming these surfaces are at ambient temperature, $T_{\mathrm{am}}$, the radiation heat transfer coefficient, $h_{\mathrm{r}}$ in Equation (8a), is given by Reference [25] as 


$$
h_{\mathrm{r}}=\varepsilon_{\mathrm{s}} \sigma\left(T_{\mathrm{s}}+T_{\mathrm{am}}\right)\left(T_{\mathrm{s}}^{2}+T_{\mathrm{am}}^{2}\right)
$$

where $\varepsilon_{\mathrm{S}}$ and $\sigma$ are the emissivity of the outer surface of the bioreactor and Stefan-Boltzmann constant $\left(5.6696 \times 10^{-8} \mathrm{~W} \cdot \mathrm{m}^{-2} \cdot \mathrm{K}^{-4}\right)$, respectively. On the outer surface of a rotating bioreactor, a mixed convection mechanism (natural and forced convection) is expected. Several correlations are reported in the literature to determine the convective coefficient $\left(h_{\mathrm{co}}\right)$ on the outer surface of high speed rotating cylinders, which are not suitable for a bioreactor rotating at low speeds. The most suitable correlation is reported by Guen et al. [26] and used to estimate $h_{\mathrm{co}}$ on the outer surface of a rotary drum reactor used for asphalt materials production; this correlation is in the following form:

$$
N u=\frac{h_{\mathrm{co}} L_{\mathrm{c}}}{K_{\mathrm{air}}}=0.135\left[0.5 R e_{\Omega}^{2}+R e_{\infty}^{2}+G r\right]^{1 / 3}
$$

where $L_{\mathrm{c}}$ is the circumferential length on the reactor surface $\left(L_{\mathrm{c}}=2 \pi \cdot r_{\mathrm{s}}\right)$ in meter. In the laboratory, the air stream velocity is very low, and the free stream Reynolds number, $R e_{\infty}$ in Equation (10) was assumed to equal zero. The rotational Reynolds number is $R e_{\Omega}=2 \Omega r_{s}^{2} / v$, in which $\Omega$ is the angular velocity of the bioreactor and $v$ is the kinematic viscosity of air. $G r$ is Grashof number on the outer surface of bioreactor, estimated at the mean temperature $\left(T_{\mathrm{am}}+T_{\mathrm{s}}\right) / 2$. To examine the suitability of Equation (10) to be used for estimating $h_{\mathrm{co}}$ in the present analysis, values of $h_{\mathrm{co}}$ were estimated, during the experiment, by using Equation (10) and compared with those estimated by using correlations for a stationary reactor, reported in Reference [14] as

$$
h_{\mathrm{co}}=1.32\left(\frac{T_{s}-T_{a m}}{\pi D}\right)^{0.25}
$$

where $D$ is the bioreactor diameter $\left(2 r_{\mathrm{s}}, \mathrm{m}\right)$. Equation (11) is for the convective coefficient on the outer surface of the horizontal cylindrical part of the bioreactor. During the composting process, the time course of $h_{\text {co }}$ values estimated by using Equation (10), at different rotational speed of reactor (i.e., 5, 10, 30, and $50 \mathrm{rpm}$ ), are illustrated in Figure 4 in comparison with those estimated from Equation (11) for the fixed reactor $(\mathrm{rpm}=0)$. Results in Figure 4 indicated that Equation $(10)$ is valid only for bioreactors rotating at a speed of $\geq 50 \mathrm{rpm}$. However, for bioreactors operating at low speed (rpm $<50$ ), the natural convection relation (Equation (11)) is recommended to estimate $h_{\mathrm{co}}$. This is because the mixed or forced convection mechanism should always result in $h_{\mathrm{co}}$ values being much higher than that of the natural convection mechanism. To this end, $Q_{\text {cylinder }}$ can be determined by calculating $U_{\text {cy }}$ as $1 / R_{\text {eq-cy }}$ (Figure 3a). To determine the convective-radiative heat loss from the side walls $\left(Q_{\text {side-wall }}\right)$, the value of $U_{\mathrm{sw}}$ was calculated as $1 / R_{\mathrm{eq}-\mathrm{sw}}$ and the resistance diagram is illustrated in Figure $3 \mathrm{~b}$. As in Equation (11), the convective coefficient at the outer surface of the side walls is given by Reference [14] as

$$
h_{\mathrm{wo}}=1.42\left(\frac{T_{\mathrm{s}}-T_{\mathrm{am}}}{D}\right)^{0.25}
$$

The bioreactor energy balance, Equation (1), is rearranged to be in the form

$$
Q_{\mathrm{gn}}=\Delta I E_{\mathrm{c}}+Q_{\text {loss }}+Q_{\mathrm{air}}
$$

where $Q_{\text {loss }}$ is the heat losses by radiation and convection (from the cylindrical surface and circular vertical side walls of the bioreactor $),\left(Q_{\text {loss }}=Q_{\text {side-wall }}+Q_{\text {cylinder }}\right)$. The heat loss with the exhausted air during the aeration process $\left(Q_{\text {air }}\right)$ was estimated as $\dot{m}_{\mathrm{a}}\left(I_{\mathrm{e}}-I_{\mathrm{am}}\right)$ and the radiation heat loss $\left(Q_{\text {rad }}\right)$ can be separately estimated as $Q_{\mathrm{rad}}=h_{\mathrm{r}}\left(A_{\mathrm{sw}}+A_{\mathrm{cy}}\right) \cdot\left(T_{\mathrm{s}}-T_{\mathrm{am}}\right) ; \Delta I E_{\mathrm{c}}$ is the rate of change of internal energy of compost. The energy terms in Equation (12) were calculated at each time interval by substituting the relevant energy terms in Equations (2)-(11) into Equation (13). The input parameters to the calculation were the measured values of $T_{\mathrm{am}}, T_{\mathrm{c}}, T_{\mathrm{s}}, R H_{\mathrm{am}}$, and the bioreactor dimensions and the thermophysical 
properties of air, compost, insulation, and bioreactor materials. The thermophysical properties were assumed to be constant values independent of temperatures. This information is listed in Table 1.

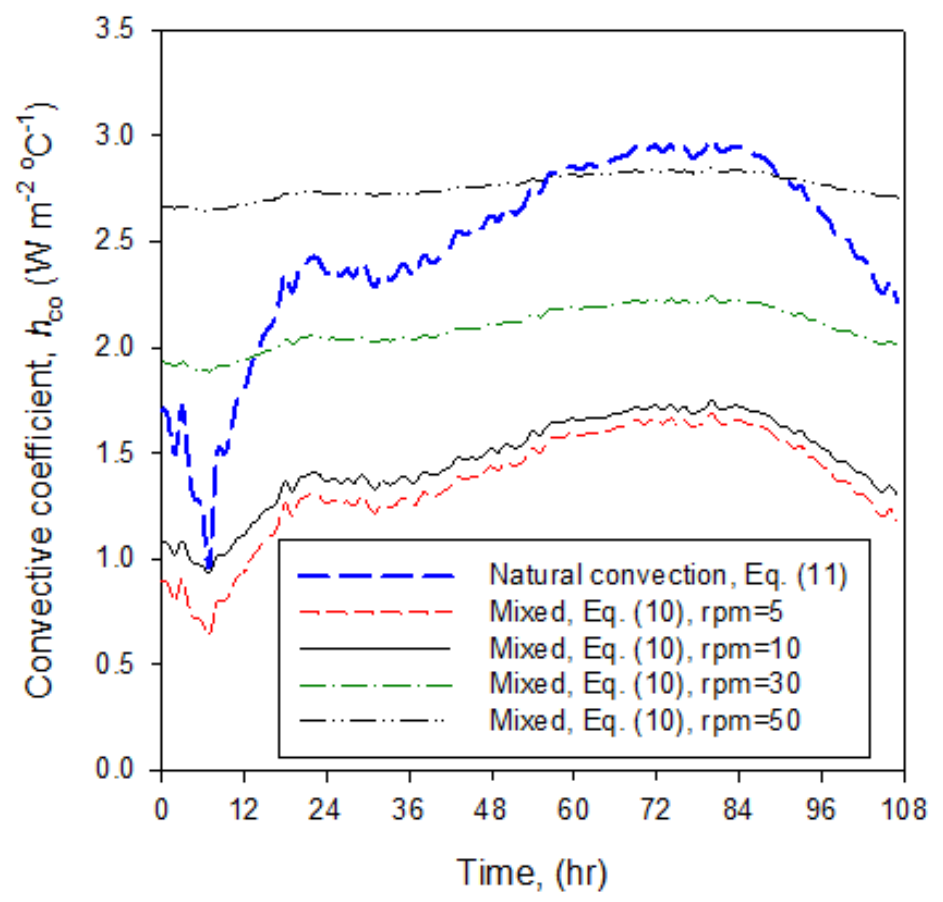

Figure 4. Convective heat transfer coefficient at the outer surface of the reactor cylinder, $h_{\mathrm{co}}\left(\mathrm{W} \cdot \mathrm{m}^{-2} \cdot{ }^{\circ} \mathrm{C}^{-1}\right)$ estimated for the mixed convection (Equation (10)) and natural convection (Equation (11)) mechanisms.

Table 1. Parameters used in the calculation of energy terms.

\begin{tabular}{ccc}
\hline Parameter & Value & Unit \\
\hline Blanket insulation & & \\
thickness, $\left(r_{\mathrm{s}}-r_{\mathrm{o}}\right)$ & 0.025 & $\mathrm{~m}$ \\
thermal conductivity, $K_{\mathrm{b}}$ & 0.04 & $\mathrm{~W} \mathrm{~m}-1{ }^{\circ} \mathrm{C}^{-1}$ \\
width, $L$ & 1.0 & $\mathrm{~m}$ \\
Steel drum & & $\mathrm{m}$ \\
diameter, $2 r_{\mathrm{O}}$ & 0.585 & $\mathrm{~m}$ \\
Length & 0.914 & $\mathrm{~m}$ \\
thickness, $\left(r_{\mathrm{o}}-r_{\mathrm{i}}\right)$ & 0.007 & $\mathrm{~J} \cdot \mathrm{kg}^{-1} \cdot{ }^{\circ} \mathrm{C}^{-1}$ \\
specific heat, $C p_{\mathrm{s}}$ & 490 & $\mathrm{~W} \cdot \mathrm{m}^{-1} \cdot{ }^{\circ} \mathrm{C}^{-1}$ \\
thermal conductivity, $K_{\mathrm{s}}$ & 46.0 & \\
Compost material & & $\mathrm{kg}$ \\
mass, $m_{\mathrm{c}}$ & 51.3 & $\mathrm{~J} \cdot \mathrm{kg}^{-1} \cdot{ }^{\circ} \mathrm{C}^{-1}$ \\
specific heat, $C p_{\mathrm{c}}$ & 1600 & $\mathrm{~m} \cdot \mathrm{min}^{-1}$ \\
Aeration & & $\mathrm{J} \cdot \mathrm{kg}^{-1} \cdot{ }^{\circ} \mathrm{C}^{-1}$ \\
mass flow rate, $\dot{m}_{a}$ & 0.005 & $\mathrm{Kg} \cdot \mathrm{m}^{-3}$ \\
specific heat, $C p_{\mathrm{a}}$ & 1007 & $\mathrm{~m}{ }^{2} \cdot \mathrm{s}^{-1}$ \\
density, $\rho$ & 1.177 & $\mathrm{~W} \cdot \mathrm{m}^{-1} \cdot{ }^{\circ} \mathrm{C}^{-1}$ \\
\hline kinematic viscosity, $\gamma$ & $1.57 \times 10^{-5}$ &
\end{tabular}

\section{Results and Discussions}

\subsection{Temperatures Profile}

The source of heat in the bioreactor is generated due to the compost metabolic reactions. This in turn increases the temperatures of the bioreactor components. The time course of the measured 
temperatures in the bioreactor (i.e., compost, $T_{\mathrm{c}}$, inner surface of bioreactor, $T_{\mathrm{i}}$, outer surface of insulation, $T_{\mathrm{s}}$, and ambient, $T_{\mathrm{am}}$ ) are illustrated in Figure 5 . The temperature of compost started to increase rapidly after the creation of composting conditions. Because of the fast breakdown of the available organic matters and nitrogenous compounds throughout microbial activities, the temperature of compost $\left(T_{\mathrm{c}}\right)$ speedily increased to about $53^{\circ} \mathrm{C}$ on the first two days and reached its maximum value $\left(66.7^{\circ} \mathrm{C}\right)$ after $72 \mathrm{~h}$ of operation. Then, it continued at higher than $60^{\circ} \mathrm{C}$ for more than $12 \mathrm{~h}$. This result was in accordance with results reported by Ghaly et al. [14] and Petric [27] for composting tomato plant residues. In Figure 5, the inner surface temperature of the bioreactor $\left(T_{i}\right)$ is nearly equal to $T_{c}$ during the first four days of operation, and after that, the maximum difference was about $4{ }^{\circ} \mathrm{C}$ at the end of operation. Accordingly, the internal heat transfer resistance, at the inner surface of the bioreactor $\left(R_{\mathrm{c} i}\right.$, in Equation (8a)) was neglected without jeopardizing the accuracy of the present analysis.

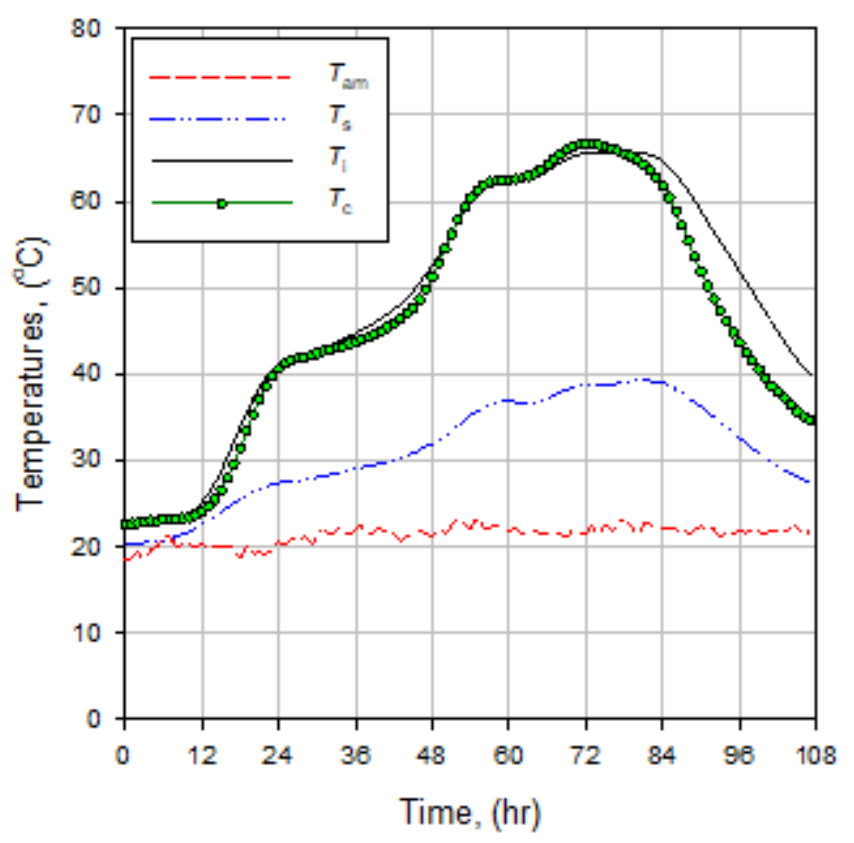

Figure 5. Time course of temperatures measured for the ambient air $\left(T_{\mathrm{am}}\right)$, outer surface of reactor $\left(T_{\mathrm{s}}\right)$, inner surface of reactor $\left(T_{\mathrm{i}}\right)$ and compost $\left(T_{\mathrm{c}}\right)$ during the composting process.

\subsection{Heat Generation and Losses}

The rate of heat generated during the composting process $\left(\mathrm{W} \cdot \mathrm{kg}^{-1}\right.$ of compost) and the accumulated heat $\left(\mathrm{kJ} \cdot \mathrm{kg}^{-1}\right)$ are illustrated in Figure 6 during the $107 \mathrm{~h}$ of composting time. As the heat was generated, the compost temperature $\left(T_{\mathrm{c}}\right)$ increased reaching $66.8^{\circ} \mathrm{C}$ at the peak time. The peak of heat generation rate was $9.3 \mathrm{~W} \cdot \mathrm{kg}^{-1}$ of organic matter reached after $72 \mathrm{~h}$ of the composting process. In total, an amount of heat totaling $1.9 \mathrm{MJ}$ per $\mathrm{kg}$ organic matter was generated during composting. Evolution of heat generation in Figure 6 depends on several parameters controlling the reaction process such as: aeration effectiveness, the humidity distribution in the compost, oxygen and nitrogen concentration, and so on. In Figure 6, reduction in the heat generation rate was observed after 18 and after $48 \mathrm{~h}$ of operation and the drastic reduction was observed after the temperature of compost $\left(T_{\mathrm{c}}\right)$ reached $66.8^{\circ} \mathrm{C}$ (cooling phase). This limit of temperature may have exceeded the optimum temperature for thermophilic microorganisms; therefore, microbial growth and activity declined. As a result, the heat production rate as well as the compost temperature drastically decreased. Another reason would be that the consumption of bioavailable nutrients by the microorganisms reduced the metabolic reaction [14]. 


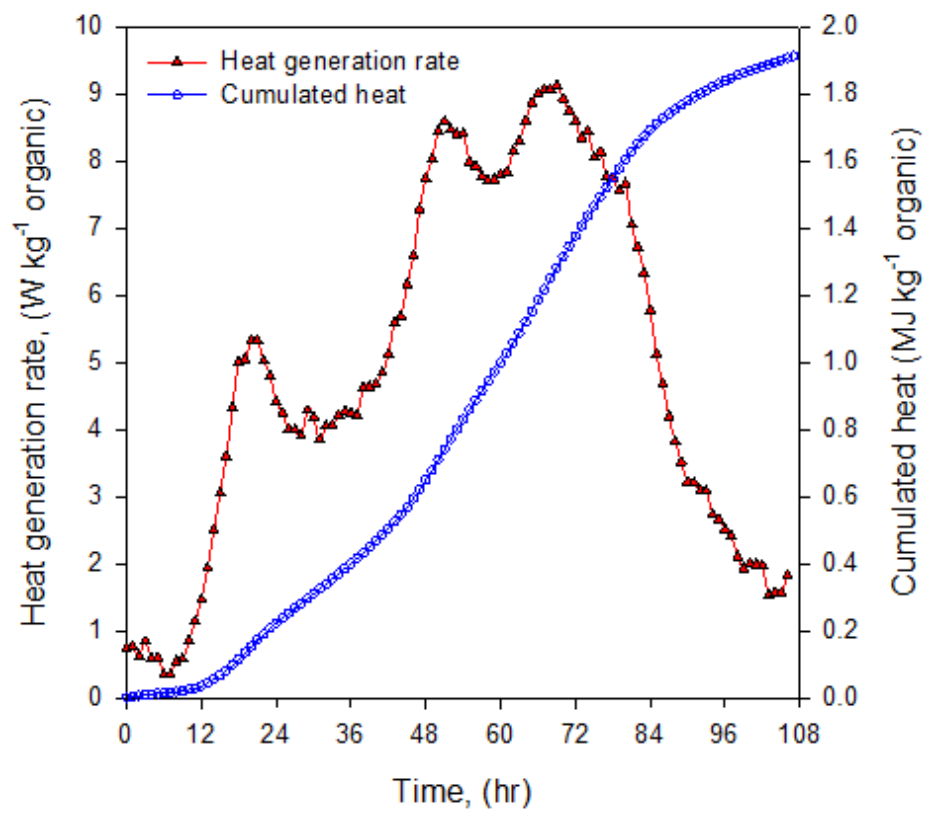

Figure 6. Time course for the heat generation rate (W) and the cumulated heat (MJ), per kg of organic matter, during the composting process.

According to Clark et al. [28] and Miller [29], the heat losses in laboratory-scale bioreactors are expected to be high due to the higher surface area to volume ratio. The convective-radiative heat loss from the outer surface of bioreactors was accounted to be in the range of $60-90 \%$ of the total heat losses $[13,14,30]$. For the present analysis, the time course of different modes of energy rate loss from inside to outside the reactor is illustrated in Figure 7. This figure showed about $96 \%$ of the generated heat was lost to outside the bioreactor via convection, radiation, and aeration processes. Due to the high surface to volume ratio, most of the heat loss ( $97 \%$ of the total loss) was lost by convection from the outer surface of the bioreactor (69\% via cylindrical body and $28 \%$ via vertical side walls). However, only $2 \%$ of the total heat loss was lost with the exhausted gas during the aeration process. The minor thermal radiation loss ( $1 \%$ of the total loss) is because the bioreactor's surroundings were the laboratory walls with an assumed equivalent temperature equal to the ambient air temperature $\left(T_{\mathrm{am}}\right)$. However, for bioreactors operating outdoors, the outer surface of the bioreactor would exchange thermal radiation with the sky dome (with an equivalent temperature, $T_{\text {sky }}$, which is much lower than the ambient temperature, $T_{\mathrm{am}}$ ). In this case, the contribution of thermal radiation loss would be much higher than the radiation loss from the indoor operated bioreactors. During composting process, the rate of change of the internal energy of compost $\left(\Delta I E_{\mathrm{c}}=m_{\mathrm{c}} C p_{\mathrm{c}}\left(d T_{\mathrm{c}} / d t\right)\right)$ was linked to the heat generation rate $\left(Q_{\mathrm{gn}}\right)$ and is illustrated in Figure 8. The rate of change of the internal energy strongly depends on the variation of heat generation as well as the compost temperature. During the temperature raise period (the active phase), the internal energy of compost increased (energy gain, positive, $+\mathrm{ve}$ ), while in the cooling phase period, the internal energy decreased (negative, -ve). Therefore, the heat gained by the compost accounted for only $4 \%$ in the form of internal energy. 


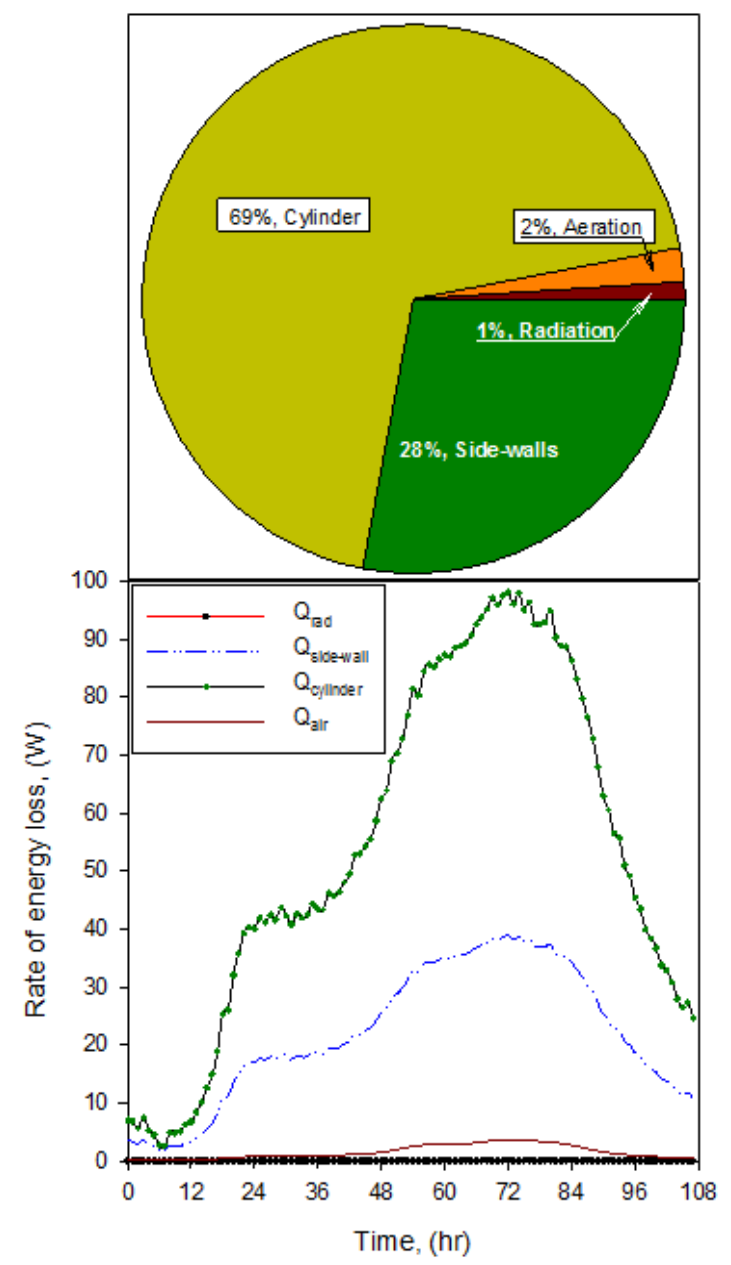

Figure 7. Energy-rate losses from inside to outside the bioreactor during the composting process via radiation, convection, and the exhausted air.

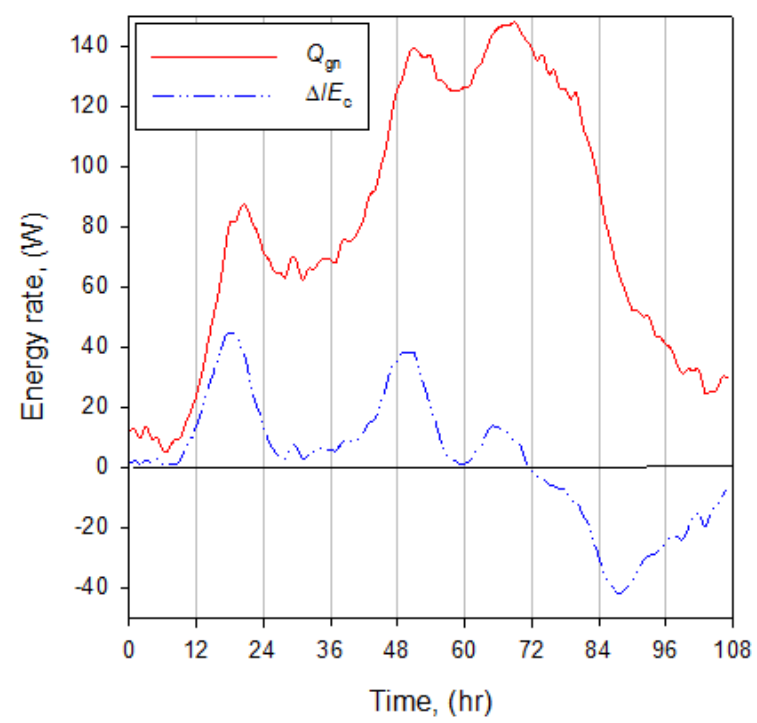

Figure 8. The total energy generation rate and the change of internal energy of compost during the composting process. 


\subsection{Composting Phases}

Under optimal conditions, beyond the lag period, composting proceeds from the initial state ( $\cong 10 \mathrm{~h}$ ) through three phases as illustrated in Figure 9. These phases are (i) the moderate-temperature phase, $\left(T_{\mathrm{c}}=25-45^{\circ} \mathrm{C}\right)$, which lasted for about one day, (ii) the high-temperature (thermophilic) phase, which lasted for two days, and (iii) the cooling and maturation phase, which lasts from one day in the bioreactor (the cooling phase in the present experiment) to several days outside the bioreactor for maturation process. Results in Figure 9 show that time consumed in the high-temperature phase could be significantly reduced to about two days compared to several days or even several months in other composting methods. However, during the thermophilic phase the temperature remained above $55^{\circ} \mathrm{C}$ for a period of $36 \mathrm{~h}$ that may enough to satisfy the regularity requirement for the destruction of pathogens. This is because compost temperatures from $52-60{ }^{\circ} \mathrm{C}$ are able to maintain the greatest thermophilic activity in composting systems and reduce weed seed viability and suppression of pathogens activity $[7,8]$.

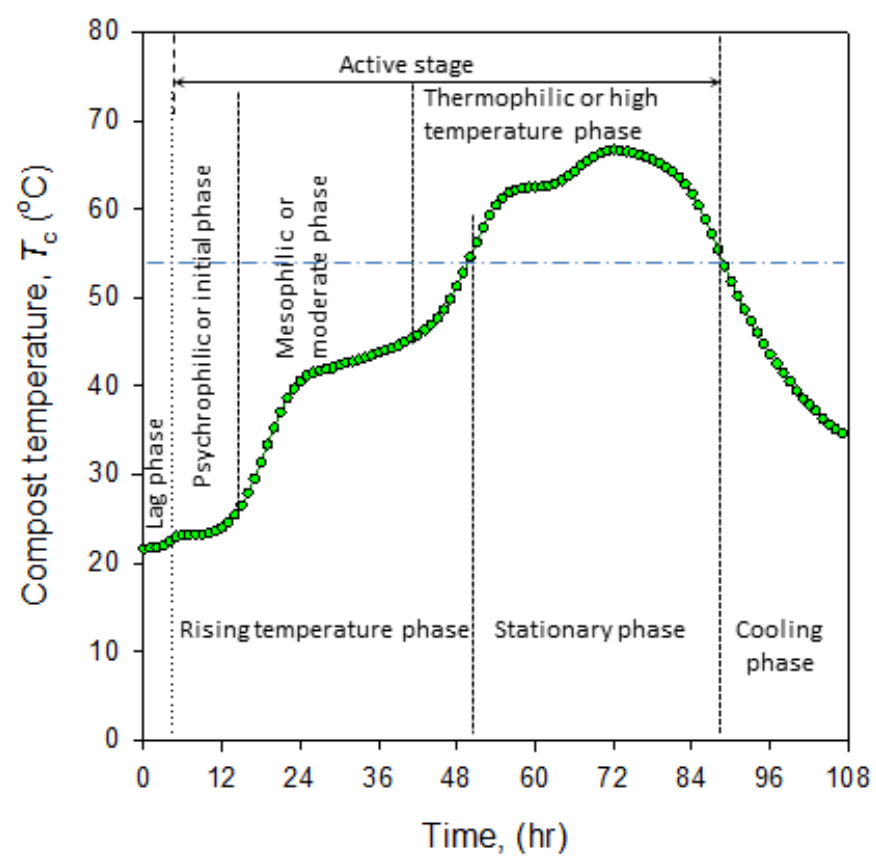

Figure 9. Composting phases were outlined based on the measured temperature of compost $\left(T_{\mathrm{c}}\right)$ in the present study.

\section{Conclusions and Recommendation}

Thermal analysis was applied to batch-operated, laboratory-scale rotary drum bioreactors used for composting tomato plant residues. The analysis was performed with a control volume, suggested to be on the inner surfaces of the bioreactor containing the compost material-moist air mixture, under unsteady state thermal conditions. The heat generated from the degradation of the organic matter raised the compost temperature, $T_{\mathrm{c}}$. According to the evolution of $T_{\mathrm{c}}$, the three main phases encountered in the composting process (lag, active, and maturation phase) could be clearly identified. The maximum heat production rate $\left(\right.$ at $T_{\mathrm{C}}=66.7^{\circ} \mathrm{C}$ ) was $9.3 \mathrm{~W} \cdot \mathrm{kg}^{-1}$ of organic matter; the rate of heat production drastically decreased after the temperature, $T_{\mathrm{c}}$, had reached $66.7^{\circ} \mathrm{C}$ due to the decline in microbial growth and activity. The total amount of heat generated during the composting process was $1.9 \mathrm{MJ}$ per $\mathrm{kg}$ organic matter; $94 \%$ of this heat was lost to outside the bioreactor, and only $4 \%$ gained by the compost material in the form of internal energy stored. The bioreactor was operated inside the laboratory. Therefore, the radiation loss was negligible ( $1 \%$ of the total heat loss). However, for bioreactors operating outdoors, radiation loss to the sky dome would be much higher and cannot be neglected. The heat 
loss with the exhaust gas accounted for $2 \%$ of the total heat loss because the aeration rate was low. Therefore, the aeration system needs to be improved to provide proper aeriation, which stimulates microbial breakdown of organic matter. This, in turn, would significantly reduce the production period. For a continually rotating drum (as in the present case), natural aeriation is suggested by making holes of appropriate size on the drum surface. The pressure difference between inside and outside the rotating drum will induced aeriation. The heat losses via convective from the outer surface of the bioreactor was extremely high ( $94 \%$ of the total heat generated). These losses can be reduced significantly by increasing the insulation effectiveness-for example, by applying reflective painting to the inner and outer surfaces of the drum, and by using radiation shields with insulation blanket. This would quickly increase the compost temperature $\left(T_{\mathrm{c}}\right)$ raise and significantly reduce the production time. Optimization is needed to keep $T_{\mathrm{c}}$ over $55^{\circ} \mathrm{C}$ as long as possible to enhance the reaction process and to suppress pathogens activity. Moreover, instead of the constant rotating speed (3 rpm) used in the present study, the effect of different speed on the composting process should be examined.

Acknowledgments: This work was supported by the National Science, Technology and Innovation Plan (NSTIP) strategic technologies program number (12-ENV2814-02) in the Kingdom of Saudi Arabia.

Author Contributions: Alkoaik and Rashwan conceived and designed the experiments; Fulleros and Ibrahim performed the experiments; Rashwan and Abdel-Ghany analyzed the data; Fulleros and Ibrahim contributed reagents/materials/analysis tools; Alkoaik and Abdel-Ghany wrote the paper.

Conflicts of Interest: The authors declare no conflict of interest. The founding sponsors had no role in the design of the study; in the collection, analyses, or interpretation of data; in the writing of the manuscript, and in the decision to publish the results.

\section{References}

1. Agriculture Statistical Annual Book (ASAB); Ministry of Environment, Water and Agriculture: Riyadh, Saudi Arabia, 2016; p. 298.

2. Alkoaik, F. Fate of Plant Pathogens and Pesticides during Composting of Greenhouse Tomato Plant Residues. Ph.D. Thesis, Dalhousie University, Halifax, NS, Canada, 2005; pp. 1-5.

3. Conway, K.E. An overview of the influence of sustainable agricultural systems on plant diseases. Crop Prot. 1996, 15, 223-228. [CrossRef]

4. Hogland, W.; Bramryd, T.; Persson, I. Physical and chemical effects of unsorted fractions of industrial solid waste in waste fuel storage. Waste Manag. Res. 1996, 14, 197-210. [CrossRef]

5. Compost Guy. Available online: http://www.compostguy.com/composting/continuous-vs-batch-composting/ (accessed on 7 December 2017).

6. Kalamdhad, A.S.; Singn, Y.K.; Ali, M.; Khwairakpam, M.; Kazmi, A.A. Rotary drum composting of vegetable waste and tree leaves. Bioresour. Technol. 2009, 100, 6442-6450. [CrossRef] [PubMed]

7. Ajay, S.K.; Kazmi, A.A. Mixed organic waste composting using rotary drum composter. Int. J. Environ. Waste Manag. 2008, 2, 24-35.

8. Ajay, S.K.; Kazmi, A.A. Effects of turning frequency on compost stability and some chemical characteristics in a rotary drum composter. Chemosphere 2009, 74, 1327-1334.

9. Rynk, R. Fires at composting facilities: Causes and conditions. Bio Cycle 2000, 41, 54-58.

10. Haug, R.T. Practical Handbook of Compost Engineering; Lewis Publishers: Boca Raton, FL, USA, 1993.

11. Rodríguez, L.; Cerrillo, M.I.; García-Albiach, V.; Villaseñor, J. Domestic sewage sludge composting in a rotary drum reactor: Optimizing the thermophilic stage. J. Environ. Manag. 2012, 112, 284-291. [CrossRef] [PubMed]

12. Stainforth, A. Cereal Straw; Clarendon: Oxford, UK, 1997.

13. Sobel, A.T.; Muck, R.E. Energy in animal manures. Energy Agric. 1983, 2, 161-176. [CrossRef]

14. Ghaly, A.E.; Alkoaik, F.; Snow, A. Thermal balance of in-vessel composting of tomato plant residues. Can. Biosyst. Eng. 2006, 48, 6.1-6.11.

15. Ahn, H.K.; Richard, T.L.; Choi, H.L. Mass and thermal balance during composting of poultry manure and wood shavings mixture at different aeration rates. Proc. Biochem. 2007, 42, 215-223. [CrossRef] 
16. Klejment, E.; Rosiński, M. Testing of thermal properties of compost from municipal waste with a view to using it as a renewable, low temperature heat source. Bioresour. Technol. 2008, 99, 8850-8855. [CrossRef] [PubMed]

17. Irvine, G.; Lamont, E.R.; Antizar-Ladislao, B. Energy from waste: Reuse of compost heat as a source of renewable energy. Int. J. Chem. Eng. 2010, 10. [CrossRef]

18. Bach, P.D.; Nakasaki, K.; Shoda, M.; Kubota, H. Thermal Balance in Composting Operations; Research Laboratory of Resources Utilization, Tokyo Institute of Technology: Yokohama, Japan, 1987.

19. Walker, I.K.; Harrison, W.J. The self-heating of wet wool. N. Z. J. Agric. Res. 1960, 3, 861-895. [CrossRef]

20. Weppen, P. Process calorimetry on composting of municipal organic wastes. Biomass Bioenergy 2001, 21, 289-299. [CrossRef]

21. Arslan, E.I.; Ünlü, A.; Topal, M. Determination of the effect of aeration rate on composting of vegetable fruit wastes. Clean Soil Air Water 2011, 39, 1014-1021. [CrossRef]

22. Iwabuchi, K.; Kimura, T.; Kamide, J. A study of the heat production rate during composting of dairy cattle feces. In Proceedings of the Symposium on Automation and Robotics in Bio-Production and Processing, Kobe, Japan, 3-6 November 1995; pp. 432-439.

23. Miller, F. Thermodynamic and Metric Water Potential Analysis in Field and Laboratory Scale Composting Ecosystem. Ph.D. Thesis, Rutgers University, New Brunswick, NJ, USA, 1984, unpublished.

24. Abdel-Ghany, A.M.; Goto, E.; Kozai, T. Evaporation characteristics in a naturally ventilated, fog-cooled greenhouse. Renew. Energy 2006, 31, 2207-2226. [CrossRef]

25. Abdel-Ghany, A.M.; Kozai, T. On the determination of the overall heat transmission coefficient and soil heat flux for a fog-cooled, naturally ventilated greenhouse: Analysis of radiation and convection heat transfer. Energy Convers. Manag. 2006, 47, 2612-2628. [CrossRef]

26. Guen, L.L.; Huchet, F.; Dumoulin, J.; Baudru, Y.; Tamagny, P. Convective heat transfer analysis in aggregates rotary drum reactor. Appl. Therm. Eng. 2013, 54, 131-139. [CrossRef]

27. Petric, I. Mathematical modeling and simulation of the composting process in a pilot reactor. In Bulletin of the Chemists and Technologists of Bosnia and Herzegovina; Department of Chemical Engineering, Faculty of Technology, University of Tuzla: Tuzla, Bosnia and Herzegovina, 2017; pp. 39-48.

28. Clark, C.S.; Buckingham, C.O.; Bone, D.H.; Clark, R.H. Laboratory scale composting: Techniques. J. Environ. Eng. 1977, 103, 893-906.

29. Miller, F.C. Composting as a process based on the control of ecologically selective factors. In Soil Microbial Ecology; Metting, F.B., Ed.; Marcel Dekker Inc.: New York, NY, USA, 1993; pp. 514-544.

30. Hogan, J.A.; Miller, F.C.; Finstein, M.S. Physical modeling of composting ecosystem. Appl. Environ. Microbiol. 1989, 55, 1082-1092. [PubMed]

(C) 2018 by the authors. Licensee MDPI, Basel, Switzerland. This article is an open access article distributed under the terms and conditions of the Creative Commons Attribution (CC BY) license (http://creativecommons.org/licenses/by/4.0/). 